\title{
FUZZY MULTI-CRITERIA AND MULTI-EXPERTS EVALUATION OF GOVERNMENT INVESTMENTS IN HIGHER EDUCATION: THE CASE OF TURKEY
}

\author{
Cengiz KAHRAMAN, Asli SUDER, Selcuk CEBI \\ Department of Industrial Engineering, İstanbul Technical University, Maçka 34367, Turkey
}

Received 27 September 2011; accepted 08 April 2012

\begin{abstract}
Higher education refers to a level of education that is provided at academies, universities, colleges, seminaries, institutes of technology, and certain other collegiate-level institutions. Government investment policy should be concerned with the marginal rate of return when deciding on whether to increase their expenditure on higher education. Government investment in higher education is a decision making problem, which includes multiple and conflicting criteria. We use fuzzy analytic hierarchy process (AHP) to take these criteria into account and to handle vague and incomplete data. We also use fuzzy TOPSIS to compare the results of AHP. A case study for Turkey is realized. In this case study, our multi-criteria decision model evaluates three possible higher education investment alternatives. A sensitivity analysis based on different scenarios of experts' preferences is also given.
\end{abstract}

Keywords: fuzzy, multi-criteria, multi-expert, government investment, higher education, AHP, TOPSIS.

Reference to this paper should be made as follows: Kahraman, C.; Suder, A.; Cebi, S. 2013. Fuzzy multi-criteria and multi-experts evaluation of government investments in higher education: the case of Turkey, Technological and Economic Development of Economy 19(4): 549-569.

JEL Classification: C63, I23.

\section{Introduction}

Higher education is an educational level that follows the completion of a school providing a secondary education, such as a high school, secondary school, or gymnasium. Higher education spending varies greatly among countries. Having investment decisions based on public signals, governments in the developing and transitional economies are forcing

Corresponding author Cengiz Kahraman

E-mail:kahramanc@itu.edu.tr 
public universities to find new sources of income (e.g. projects through industry-university collaboration). Faced with the enormous demand for foreign qualifications coupled with a lack of capacity to deliver high standards of training, these universities are themselves increasingly looking to form partnerships with foreign universities and other examination bodies in order to offer validated courses. Newly formed professional organizations sought to negotiate accreditation agreements with their counterparts. Another emerging trend is that governments are also requesting internationally recognized examination bodies to 'benchmark' national qualifications and in some cases, to import entire training systems (Bennell, Pearce 2012).

In today's world, universities are becoming more and more diverse and constantly changing in response to environmental uncertainty and increasing international competition. The internationalization of higher education provision, especially among universities in developed industrial countries, has been consistently identified as a major trend since the late 1980s. This process of internationalization is manifesting itself in a variety of ways. Not only are changes of faculty and students becoming increasingly common but also the universities are striving to respond to the needs of the rapidly globalizing economy by internationalizing their curricula. The rapid internationalization of education and training markets through the use of distance education is a direct consequence of rapid globalization since the mid1980s. Consequently, the mass provision of high quality higher education as part of a process of lifelong learning is crucial in order to meet the knowledge and skill needs of the sectors. Today, governments consider investments in the internationalization of higher education as a necessity (Bennell, Pearce 2003).

There are totally 141 universities in Turkey, 97 of which are state owned and the rest are sponsored by individual foundations. There is a keen competition among Turkish universities in the international field. In Turkish universities, externally motivated change may involve technology, competition between international universities, state universities and private universities, and demands from students. Internally motivated change may involve new managerial policies and styles, systems and procedures and members attitudes. Universities can stimulate innovation by having flexible structures, easy access to resources, and fluid communication. Innovation is also stimulated by a relaxed culture and supportive of new ideas. It encourages monitoring of the environment and needs well trained creative people. The Turkish government plans to invest in new universities in order to increase innovative studies and to compete among international universities.

The Ministry of National Education in Turkey, the State Planning Organization Undersecretariat and the Ministry of Finance are responsible for planning educational investments. These organizations identify employment policies using strategies in conformance to the development plans and educational investment requirements and resources. Fig. 1 illustrates the higher education structures in Turkey. First, decisions are made to balance the educational investment requirements and investment resources for an education that is suitable for the nation's circumstances, then educational investments are programmed and produced. Thus, the objectives at various educational levels are defined by development plans and directed by education councils. Using the results of these efforts, the existing stocks of the educational structure in the country are assessed and general and local distribution of the need for 


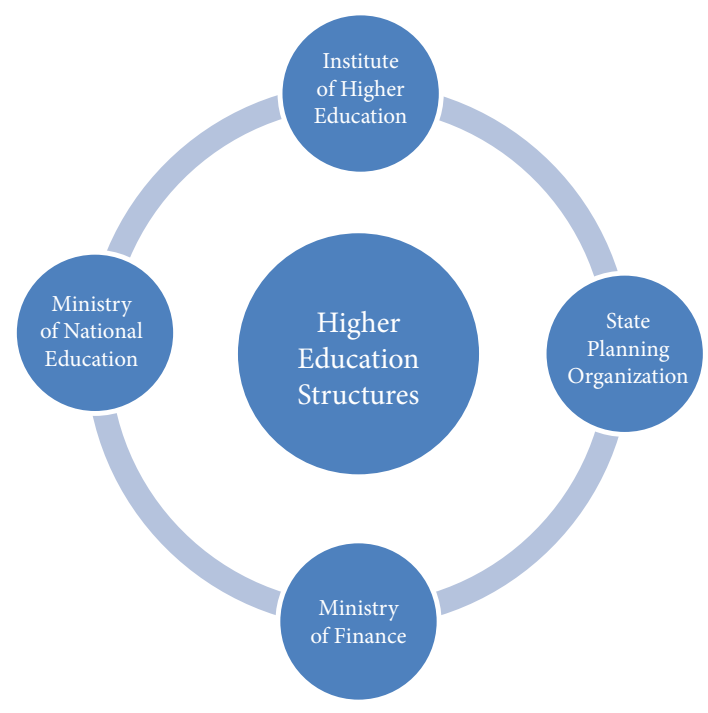

Fig. 1. Higher education structures in Turkey

educational structures are identified. Educational investments are performed through the following stages: planning, programming, projecting, execution (performance), operation, maintenance-repair, and evaluation.

There is not much research on investments in higher education in the literature. Gradstein and Justman (1995) study competitive investment in higher education and state that when aggregate advanced skills determine an economy's capacity to attract external capital they function as an 'impure' public good. Education subsidies are indicated, but Nash equilibrium in education policies yields excessive subsidies if the supply of capital is not elastic. Voon (2001) uses the growth model involving an aggregate production function to measure the social benefits from human capital improvements due to the investments in higher education. Social welfare benefits reported in this paper encompass the overall effects of labour force quality improvement on real GDP growth. Social returns from Hong Kong's investments in higher education calculated using the production function approach are significantly larger than those computed using the wage increment method. Andersson et al. (2009) investigate the economic effects of the decentralization policy on the level of productivity and innovation and their spatial distribution in the Swedish national economy. They find important and significant effects of this investment policy upon economic output and the locus of knowledge production, suggesting that the decentralization has affected regional development through local innovation and increased creativity. Arcalean and Schiopu (2010) study the interaction between public and private spending in a two-stage education framework, which are the multiple funding trade-offs associated with basic (K-12) and advanced (tertiary) education stages, and their effects on economic growth. They find that an increase in the overall education public spending crowds out the total level of private contributions and increases the share of resources that households devote to K-12 education. 
552 C. Kahraman et al. Fuzzy multi-criteria and multi-experts evaluation of government investments...

Evaluation of Government Investments is a multi-criteria problem since it includes many conflicting criteria. There are various approaches to multi-criteria problems in the literature. Among them we can count analytic hierarchy process, TOPSIS, VIKOR, and ELECTRE.

Humans are unsuccessful in making quantitative judgments, whereas they are comparatively efficient in qualitative judgments. This is why the fuzzy set theory is preferred in this study. Wei (2011) proposes the priority based on possibility degree for the fuzzy multiple attribute decision making problem. For the determination of the weights of criteria, fuzzy AHP can be used since it is based on pairwise comparisons and allows utilization of linguistic variables. The fuzzy set theory was introduced by Zadeh (1965) to express the linguistic terms in decision-making process in order to resolve the vagueness, ambiguity and subjectivity of human judgment. A relative scale of measurement is derived from dual comparisons of criteria. The pairwise comparison approach is a demanding approach in terms of solicited input from the experts; nevertheless, it offers maximum insight, particularly in terms of assessing consistency of the experts' judgment. This technique is ideal for the examination of a selected set of evaluation criteria in higher education investments.

The goal of this paper is to make a fuzzy multi-criteria and multi-experts evaluation of government investment alternatives in higher education. The fuzzy analytic hierarchy process method developed by Buckley (1985) is used for this multi-criteria analysis. The evaluation model is applied to the case of Turkey.

The rest of the paper is organized as follows. Section 1 presents government investment criteria and alternatives in higher education. Section 2 includes the fuzzy AHP method. Section 3 gives the application of the proposed evaluation model to the case of Turkey. Conclusions are presented in the final section.

\section{Government investment criteria and alternatives in Higher Education}

Turkish government has four main investment criteria for higher education investments. The first criterion is promoting involvement by other public sector and private sector bodies in projects. The second criterion is creating jobs, skills and markets for products and services and supporting research and technological development. Turkish government tries to encourage public sector and private sector in establishing universities that have high quality standards and research advantages. The third criterion is promoting competition among institutions and transparency in public funding. Competition among universities in the international and national areas makes investment decisions more important and strategic. The fourth criterion is promoting greater collaboration among institutions and with external firms and other organizations. There are many examples of the ability and willingness of the universities to collaborate in major research areas like advanced technology, genetic engineering, and nanotechnology. New laboratories and technology parks are the fundamental sources for collaboration among institutions. New laboratories extend the university's research areas that go beyond boundaries of traditional departments and require mutual effort by faculty from various disciplines. Technology park strives for the highest standards of professionalism to ensure that functions and events are presented 
exactly in accordance with governments' needs. Technology park function centre and innovation centre can be together and work more effectively.

Government must choose the most effective alternative among the following three investment alternatives:

New universities in a region. Great efforts have been spent for establishing new universities in the recent years in Turkey. It has always been a problem where a new university should be established in Turkey. About $30 \%$ of the universities are located in Istanbul whereas $20 \%$ of the 81 cities do not have any university.

Extension of existing universities in a region. This alternative has been partially applied in the past in Turkey. Recently, few universities have begun to extend their facilities to other regions. For instance, the universities ITU and METU extended their facilities in Cyprus.

Combination of existing universities. The combination of open universities or conventional universities offers the possibility of combining strategies and exchanging expertise, maybe even building strategic partnerships. The more experienced universities will present their business models and institutional strategies to less experienced universities. This alternative has been also partially applied in the past in Turkey. Combination of the existing universities needs to be invested in new facilities. No combination of universities has been realized in the recent years in Turkey.

Fig. 2 illustrates the hierarchy between these criteria and alternatives. Table 1 presents the meanings of the symbols in Fig. 2.

Table 1. The evaluation criteria

\begin{tabular}{lll}
\hline \multicolumn{1}{l}{ Abbreviation } & Criteria \\
\hline C & & The best investment in higher education \\
\hline & & Promoting involvement by other public sector and private sector bodies in projects \\
\hline & C11 & Public sector \\
& C12 & Private sector \\
\hline C2 & & $\begin{array}{l}\text { Creating jobs, skills and markets for products and services and supporting } \\
\text { research and technological development }\end{array}$ \\
\hline & C21 & New labs \\
\hline C3 & C22 & Technology park \\
\hline & C31 & International competition \\
\hline C32 & National competition \\
\hline C4 & $\begin{array}{l}\text { Promoting greater collaboration among institutions and with external firms and } \\
\text { other organizations }\end{array}$ \\
\hline & C41 & Collaboration with external firms \\
\hline C42 & Collaboration among institutions \\
\hline
\end{tabular}


554 C. Kahraman et al. Fuzzy multi-criteria and multi-experts evaluation of government investments...

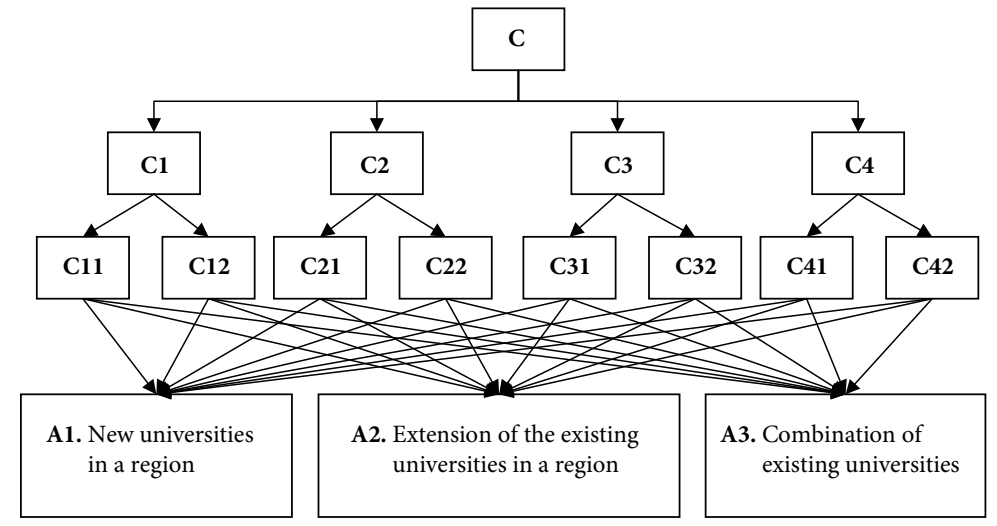

Fig. 2. Hierarchy of criteria and alternatives

\section{Multi-criteria method: Buckley's fuzzy AHP}

Buckley's (1985) AHP is the extension of the traditional AHP method which incorporates fuzzy comparison ratios. In Buckley's approach, geometric mean method is used to derive fuzzy weights and performance scores. There are a number of works using Buckley's fuzzy AHP method: Cebeci (2009) presents an approach to select a suitable ERP system for textile industry. Javanbarg et al. (2012) present a fuzzy optimization model for particle swarm optimization to solve multicriteria decision making (MCDM) problems using fuzzy analytic hierarchy processes. Kaya and Kahraman (2011) propose an environmental impact assessment methodology based on an integrated fuzzy AHP-ELECTRE approach in the context of urban industrial planning. In the proposed methodology the criteria weights are generated by a fuzzy AHP procedure. Lo and Wen (2010) propose a fuzzy-AHP-based technique and construct a hierarchical system structure for Massively Multiplayer Online Role-Playing Game design, which includes two systems, nine design components and 36 design features for the design factor trade-off problem. Azadeh et al. (2010) give a solution to the problem of mining method selection (MMS) in mining projects. In order to resolve the problems of weighting, analytic hierarchy process is applied. Celik et al. (2009) propose a fuzzy integrated multi-stages evaluation model under multiple criteria in order to manage the academic personnel selection and development processes in Maritime Education and Training institutions. Jaskowski et al. (2010) suggest the application of an extended fuzzy AHP method to the process of group decision making. Their approach facilitates defining criteria weights by aggregation of decision makers' judgments. Tiryaki and Ahlatcioglu (2009) combine the fuzzy analytic hierarchy process (AHP) with the portfolio selection problem. Hsu (2012) discusses the service attributes of ports for ship navigation safety. Based on the relevant literature and the features of ship navigation in ports, the service attributes of ports for ship navigation are first investigated. A fuzzy AHP model is then used to identify those attributes from shipmasters' perspectives. Pan (2009) presents a fuzzy AHP approach to cope with this problem and be an attempt in the determination of a suitable excavation construction method. Lavasani et al. (2011) use analytical hierarchy process to estimate weights required for grouping 
non-commensurate risk sources. Chen et al. (2011) describe the design of a fuzzy decision support system in multi-criteria analysis approach for selecting the best plan alternatives or strategies in environment watershed. The fuzzy analytic hierarchy process (FAHP) method is used to determine the preference weightings of criteria for decision makers by subjective perception (natural language). Kahraman and Cebi (2009) add three important tolls to fuzzy axiomatic design method so as to supply its deficiency. The first one is the hierarchy which has the ability of taking the hierarchical structures into account. The second is the crisp toll which has the ability of taking the positive information into consideration under fuzzy environment. The last one is the ranking ability.

The FAHP is preferred due to its simple nature in order to extend the fuzzy case and it guarantees a unique solution to the reciprocal comparison matrix. The evaluation procedure is summarized as follows (Chen, Hwang 1992; Hsieh et al. 2004):

Step 1. An expert team is established. Since the quality of the evaluation procedure depends on experts' knowledge and experiences, the members of the team must be from a range of experts with different background/discipline.

Step 2. Evaluation criteria are determined. Literature and questionnaires helps the expert to determine evaluation criteria. The members in the team are required to review all information related to the education system and education strategies in Turkey. After all factors affecting the final decision are determined, the hierarchy including alternatives is constructed.

Step 3. Pairwise comparison matrices are constructed. Each element $\left(\tilde{c}_{i j}\right)$ of the pairwise comparison matrix $(\tilde{C})$ is a linguistic term indicating which one of the two criteria is more important. The pairwise comparison matrix is given by Eq. (1) for any expert.

$$
\tilde{C}_{k}=\left|\begin{array}{cccc}
1 & \tilde{c}_{12} & \cdots & \tilde{c}_{1 n} \\
\tilde{c}_{12} & 1 & \cdots & \tilde{c}_{2 n} \\
\vdots & \vdots & : \vdots & \vdots \\
\tilde{c}_{n 1} & \tilde{c}_{n 2} & \cdots & 1
\end{array}\right|, \quad k=1,2,3, \ldots, K,
$$

where: $n$ is the number of criteria; $\tilde{C}_{k}$ is a pairwise comparison matrix belongs to $k^{\text {th }}$ expert for $F R_{m}$. For the evaluation procedure, the linguistic terms given in Table 2 are used. Arithmetic mean is used to aggregate experts' opinions.

$$
\tilde{C}=\frac{1}{K}\left(\tilde{C}^{1}+\tilde{C}^{2}+\tilde{C}^{3}+\ldots+\tilde{C}^{K}\right) .
$$

As an alternative way to arithmetic mean method used for aggregation, a consensus matrix can be constructed to aggregate experts' opinions.

Table 2. Linguistic scale for weight matrix (Hsieh et al. 2004)

\begin{tabular}{cll}
\hline Scale of fuzzy numbers & Linguistic scales & \\
\hline$(1,1,1)$ & Just equal & (Je) \\
$(1,1,3)$ & Almost equally important & $(\mathrm{Eq})$ \\
$(1,3,5)$ & Weakly important & $(\mathrm{Wk})$ \\
$(3,5,7)$ & Essentially important & $(\mathrm{Es})$ \\
$(5,7,9)$ & Very strongly important & $(\mathrm{Vs})$ \\
$(7,9,9)$ & Absolutely important & $(\mathrm{Ab})$ \\
\hline
\end{tabular}


556 C. Kahraman et al. Fuzzy multi-criteria and multi-experts evaluation of government investments...

Step 4. The linguistic terms are transformed into triangular fuzzy numbers. The triangular fuzzy numbers given in Table 2 are used for transformation.

Step 5. Weights are calculated. At first, the fuzzy weight matrix is calculated by Buckley's method as follows (Hsieh et al. 2004):

$$
\begin{gathered}
\tilde{r}_{i}=\left(\tilde{c}_{i 1} \otimes \tilde{c}_{i 2} \otimes \ldots \otimes \tilde{c}_{i n}\right)^{1 / n} ; \\
\tilde{w}_{i}=\tilde{r}_{i} \otimes\left(\tilde{r}_{1}+\tilde{r}_{2}+\ldots+\tilde{r}_{n}\right)^{-1},
\end{gathered}
$$

where: $\tilde{r}_{i}$ is the geometric mean of fuzzy comparison value; $\tilde{w}_{i}$ indicated by triangular fuzy numbers $\tilde{w}_{i}\left(L_{i}, M_{i}, U_{i}\right)$ is the fuzzy weight of $i^{\text {th }}$ criterion. After the fuzzy relative weight matrix is obtained, the defuzzification process which converts a fuzzy number into a crisp value is utilized. At first, fuzzy numbers will be defuzzified into crisp values and then normalization procedure will be applied. For the defuzzification process, centroid method, which provides a crisp value based on the centre of the gravity, is selected since it is the most commonly used method (Opricovic, Tzeng 2004).

$$
w_{i}=\frac{\tilde{w}_{i}}{\sum_{j=1}^{n} \tilde{w}_{j}}=\frac{L_{i}+M_{i}+U_{i}}{\sum_{j=1}^{n} \tilde{w}_{j}} .
$$

Consistency of the pairwise comparison matrices should be checked by defuzzifying the fuzzy numbers in the matrices and then calculating their consistency ratios as in the classical way.

Step 6. By using the weights of criteria and alternatives, the best alternative is selected.

\section{Application: the case of Turkey}

We consider possible investment alternatives in higher education for the Marmara Region of Turkey. Being the main industrial region of Turkey, the Marmara region forms a passage between the Balkan Peninsula and Anatolia. Europe and Asia are connected to each other in this region. It gets its name from the internal sea with the same name, which is entirely surrounded by land and connected to the Black Sea and the Aegean Sea through the straits. The people in the Marmara Region make their living in industry, trade, tourism and agriculture. The most developed industrial zone in the region is the Istanbul-Bursa-Izmit triangle. Istanbul, which has been an important trade centre since ancient times and is located on the intercontinental transport routes, makes the region superior throughout the country. The region is the financial, investment, education and operations centre of Turkey. In the Marmara Region, there are 15 government universities and 20 foundation universities. Turkish government plans investing in new government universities in the Marmara Region since the existing higher education facilities do not meet the needs of young population in this region. The investment alternatives given in Section 1 are considered for the Marmara Region in our case. 


\subsection{Fuzzy AHP}

In the following, the steps of the methodology given in Section 2 are applied for the considered problem:

Step 1. Our expert team consists of three experts from State Planning Organization, Ministry of National Education, and Institute of Higher Education.

Step 2. The determined criteria have already been given in Table 1 and the hierarchy of the criteria and alternatives has been given in Fig. 2.

Step 3. In the evaluation step, several surveys are realized. At first, pairwise comparison matrices are constructed by the team members individually (Tables A1-A3 in the Appendix). Then a consensus matrix is presented by the expert team. After these, each expert evaluates the alternatives using a linguistic scale in order to calculate validation of evaluations (Table A4 in the Appendix). The consensus pairwise matrices are presented in Table 3.

Step 4. The linguistic terms in the comparison matrices are transformed into triangular fuzzy numbers given in Table 2 . The triangular fuzzy numbers are presented in Table 4 .

Step 5. The final weights of the alternatives given in Table 5 are obtained by using Eqs. (3-5). The consistency ratios of the comparison matrices are checked if they are at most 0.1 .

Step 6. According to Table 5, the best investment in higher education is the extension of the existing universities in Marmara region. The next one is the new universities in Marmara region.

An illustrative example for weights of subcriteria C11 and C12 is given below: by using Eq. (3),

$$
\begin{aligned}
& \tilde{r}_{C 11}=\left(\tilde{c}_{C 11 C 11} \otimes \tilde{c}_{C 11 C 12}\right)^{1 / 2} \\
& \tilde{r}_{C 11}=((1,1,1) \otimes(3,5,7))^{1 / 2}, \\
& \tilde{r}_{C 11}=(1.73,2.24,2.65)
\end{aligned}
$$

\begin{tabular}{|c|c|c|c|c|c|c|c|c|c|c|c|c|c|c|c|c|c|c|c|}
\hline C & C1 & C2 & C3 & C4 & & C1 & C11 & C12 & $\mathrm{C} 2$ & C21 & C22 & & C3 & C31 & C32 & & $\mathrm{C} 4$ & C41 & $\mathrm{C} 42$ \\
\hline $\mathrm{C} 1$ & & $1 / \mathrm{Vs}$ & $\mathrm{Wk}$ & $1 /$ Es & & C11 & & Es & C21 & & $1 / \mathrm{Vs}$ & & C31 & & Vs & & C41 & & $1 / \mathrm{Wk}$ \\
\hline $\mathrm{C} 2$ & & & Vs & Es & & $\mathrm{C} 12$ & & & C22 & & & & C32 & & & & $\mathrm{C} 42$ & & \\
\hline C3 & & & & $1 / \mathrm{Es}$ & & & & & & & & & & & & & & & \\
\hline \multicolumn{20}{|l|}{$\mathrm{C4}$} \\
\hline C11 & A1 & A2 & A3 & & $\mathrm{C} 12$ & A1 & A2 & A3 & C21 & A1 & A2 & A3 & & C22 & A1 & A2 & A3 & & \\
\hline A1 & & $1 / \mathrm{Es}$ & Wk & & A1 & & $1 /$ Es & $1 / \mathrm{Wk}$ & A1 & & $1 / \mathrm{Eq}$ & Es & & A1 & & $\mathrm{Eq}$ & $1 / \mathrm{Wk}$ & & \\
\hline A2 & & & Es & & A2 & & & Vs & A2 & & & Vs & & A2 & & & Es & & \\
\hline A3 & & & & & A3 & & & & A3 & & & & & A3 & & & & & \\
\hline C31 & A1 & A2 & A3 & & C32 & A1 & A2 & A3 & C41 & A1 & A2 & A3 & & $\mathrm{C} 42$ & A1 & A2 & A3 & & \\
\hline A1 & & $1 / \mathrm{Vs}$ & $1 / \mathrm{Vs}$ & & A1 & & $1 /$ Es & Wk & A1 & & $1 /$ Es & $\mathrm{Eq}$ & & A1 & & $1 / \mathrm{Wk}$ & $\mathrm{Eq}$ & & \\
\hline A2 & & & $\mathrm{Eq}$ & & A2 & & & Vs & A2 & & & Wk & & A2 & & & Wk & & \\
\hline A3 & & & & & A3 & & & & A3 & & & & & A3 & & & & & \\
\hline
\end{tabular}

Table 3. Expert evaluations 
558 C. Kahraman et al. Fuzzy multi-criteria and multi-experts evaluation of government investments...

Table 4. Triangular fuzzy numbers for linguistic variables

\begin{tabular}{|c|c|c|c|c|c|c|c|c|c|c|c|c|c|c|c|c|c|c|}
\hline C & $\mathrm{C} 1$ & $\mathrm{C} 2$ & $\mathrm{C} 3$ & $\mathrm{C} 4$ & $\mathrm{C} 1$ & C11 & $\mathrm{C} 12$ & $\mathrm{C} 2$ & $\mathrm{C} 21$ & $\mathrm{C} 22$ & & $\mathrm{C} 3$ & C31 & $\mathrm{C} 32$ & & $\mathrm{C} 4$ & C41 & $\mathrm{C} 42$ \\
\hline $\mathrm{C} 1$ & $(1,1,1)$ & $1 /(5,7,9)$ & $(1,3,5)$ & $1 /(3,5,7)$ & C11 & $(1,1,1)$ & $(3,5,7)$ & $\mathrm{C} 21$ & $(1,1,1)$ & $1 /(5,7,9)$ & & $\mathrm{C} 31$ & $(1,1,1)$ & $(5,7,9)$ & & C41 & $(1,1,1)$ & $1 /(1,3,5)$ \\
\hline $\mathrm{C} 2$ & & $(1,1,1)$ & $(5,7,9)$ & $(3,5,7)$ & $\mathrm{C} 12$ & & $(1,1,1)$ & $\mathrm{C} 22$ & & $(1,1,1)$ & & $\mathrm{C} 32$ & & $(1,1,1)$ & & $\mathrm{C} 42$ & & $(1,1,1)$ \\
\hline $\mathrm{C} 3$ & & & $(1,1,1)$ & $1 /(3,5,7)$ & & & & & & & & & & & & & & \\
\hline $\mathrm{C} 4$ & & & & $(1,1,1)$ & & & & & & & & & & & & & & \\
\hline C11 & $1 \mathrm{~A} 1$ & A2 & A3 & $\mathrm{C} 12$ & A1 & A2 & A3 & C21 & A1 & A2 & A3 & & $\mathrm{C} 22$ & A1 & A2 & A3 & & \\
\hline Al & $(1,1,1)$ & $1 /(3,5,7)$ & $(1,3,5)$ & $\mathrm{A} 1$ & $(1,1,1)$ & $1 /(3,5,7)$ & ) $1 /(1,3,5)$ & ) $\mathrm{A} 1$ & $(1,1,1)$ & $1 /(1,1,3)$ & $(3,5,7)$ & & A1 & $(1,1,1)$ & $(1,1,3)$ & $1 /(1,3,5)$ & & \\
\hline A2 & & $(1,1,1)$ & $(3,5,7)$ & $\mathrm{A} 2$ & & $(1,1,1)$ & $(5,7,9)$ & A2 & & $(1,1,1)$ & $(5,7,9)$ & & A2 & & $(1,1,1)$ & $(3,5,7)$ & & \\
\hline $\mathrm{A} 3$ & & & $(1,1,1)$ & $\mathrm{A} 3$ & & & $(1,1,1)$ & $\mathrm{A} 3$ & & & $(1,1,1)$ & & A3 & & & $(1,1,1)$ & & \\
\hline C31 & $1 \mathrm{~A} 1$ & A2 & A3 & C32 & $\mathrm{A} 1$ & A2 & A3 & C41 & A1 & A2 & A3 & & $\mathrm{C} 42$ & A1 & A2 & A3 & & \\
\hline Al & $(1,1,1)$ & $1 /(5,7,9)$ & $1 /(5,7,9$ & $\mathrm{A} 1$ & $(1,1,1)$ & $1 /(3,5,7)$ & $(1,3,5)$ & A1 & $(1,1,1)$ & $1 /(3,5,7)$ & $(1,1,3)$ & & A1 & $(1,1,1)$ & $1 /(1,3,5)$ & $(1,1,3)$ & & \\
\hline A2 & & $(1,1,1)$ & $(1,1,3)$ & $\mathrm{A} 2$ & & $(1,1,1)$ & $(5,7,9)$ & A2 & & $(1,1,1)$ & $(1,3,5)$ & & A2 & & $(1,1,1)$ & $(1,3,5)$ & & \\
\hline A3 & & & $(1,1,1)$ & $\mathrm{A} 3$ & & & $(1,1,1)$ & A3 & & & $(1,1,1)$ & & A3 & & & $(1,1,1)$ & & \\
\hline
\end{tabular}

Table 5. Final Weights

\begin{tabular}{cccccccccc}
\hline & \multicolumn{2}{c}{$\mathrm{C}_{1}$} & \multicolumn{2}{c}{$\mathrm{C}_{2}$} & \multicolumn{2}{c}{$\mathrm{C}_{3}$} & \multicolumn{2}{c}{$\mathrm{C}_{4}$} \\
\hline & & 0.09 & & \multicolumn{2}{c}{0.61} & \multicolumn{2}{c}{0.06} & \multicolumn{2}{c}{0.24} \\
\hline & $\mathrm{C}_{11}$ & $\mathrm{C}_{12}$ & $\mathrm{C}_{21}$ & $\mathrm{C}_{22}$ & $\mathrm{C}_{31}$ & $\mathrm{C}_{32}$ & $\mathrm{C}_{41}$ & $\mathrm{C}_{42}$ & \\
\hline & 0.82 & 0.18 & 0.13 & 0.87 & 0.87 & 0.13 & 0.29 & 0.71 & $\mathrm{~W}$ \\
\hline $\mathrm{A}_{1}$ & 0.26 & 0.12 & 0.61 & 0.40 & 0.07 & 0.24 & 0.23 & 0.34 & 0.36 \\
\hline $\mathrm{A}_{2}$ & 0.86 & 0.81 & 0.87 & 0.64 & 0.56 & 0.89 & 0.77 & 0.74 & 0.70 \\
\hline $\mathrm{A}_{3}$ & 0.14 & 0.19 & 0.13 & 0.36 & 0.44 & 0.11 & 0.23 & 0.26 & 0.30 \\
\hline
\end{tabular}

is obtained and $\tilde{r}_{C 22}$ is calculated as $(0.38,0.45,0.58)$. By using Eq. (4),

$$
\begin{aligned}
& \tilde{w}_{C 11}=\tilde{r}_{C 11} \otimes\left(\tilde{r}_{C 11}+\tilde{r}_{C 12}\right)^{-1} \\
& \tilde{w}_{C 11}=(1.73,2.24,2.65) \otimes[(1.73,2.24,2.65)+(0.38,0.45,0.58)]^{-1} \\
& \tilde{w}_{C 11}=(0.54,0.83,1.25)
\end{aligned}
$$

is obtained and $\tilde{w}_{C 12}$ is calculated as $(0.12,0.17,0.27)$. By using Eq. (5),

$$
\begin{aligned}
& w_{C 11}=\frac{\tilde{w}_{C 11}}{\sum_{j=1}^{2} \tilde{w}_{C 1 j}}=\frac{L_{C 11}+M_{C 11}+U_{C 11}}{\tilde{w}_{C 11}+\tilde{w}_{C 12}} \\
& w_{C 11}=\frac{(0.54+0.83+1.25)}{(0.54+0.83+1.25+0.12+0.17+0.27)} \\
& w_{C 11}=0.82
\end{aligned}
$$


is obtained and $w_{\mathrm{C} 12}$ is calculated as 0.18 . The same calculation procedure is applied for all pairwise comparisons. Then, $W_{A 1}$ is obtained as follows:

$$
\begin{aligned}
W_{A 1}= & 0.09 \times 0.82 \times 0.26+0.09 \times 0.18 \times 0.12+0.61 \times 0.13 \times 0.61+0.61 \times 0.87 \times 0.40+ \\
& 0.06 \times 0.87 \times 0.07+0.06 \times 0.13 \times 0.24+0.24 \times 0.29 \times 0.23+0.24 \times 0.71 \times 0.34 ; \\
W_{A 1}= & 0.36
\end{aligned}
$$

\subsection{Sensitivity analysis}

In this section, different scenarios are taken into consideration based on experts' preferences given in Tables A1-A3 in the Appendix. At first, the calculation procedure given above is applied for each expert's preferences. Then four different weighting scenarios are implemented to obtain a joint decision matrix. These scenarios are given in Table 6 .

Table 7 presents the ranking scores with respect to each expert. The criteria weights differ from one expert to another.

The results are illustrated in Fig. 3.

Table 6. Weighting scenarios

\begin{tabular}{|c|c|c|c|c|c|c|c|c|c|}
\hline $\begin{array}{c}\text { Scenarios } \\
\text { Ranking } \\
\text { Scores }\end{array}$ & \multicolumn{9}{|c|}{ Criteria (Weights) } \\
\hline \multirow[t]{2}{*}{ Expert 1} & \multicolumn{2}{|c|}{$\mathrm{C}_{1}(0.13)$} & \multicolumn{2}{|c|}{$\mathrm{C}_{2}(0.54)$} & \multicolumn{2}{|c|}{$\mathrm{C}_{3}(0.06)$} & \multicolumn{2}{|c|}{$\mathrm{C}_{4}(0.26)$} & $\mathbf{W}$ \\
\hline & $\mathrm{C}_{11}(0.87)$ & $\mathrm{C}_{12}(0.13)$ & $\mathrm{C}_{21}(0.13)$ & $\mathrm{C}_{22}(0.87)$ & $\mathrm{C}_{31}(0.87)$ & $\mathrm{C}_{32}(0.13)$ & $\mathrm{C}_{41}(0.29)$ & $\mathrm{C}_{42}(0.71)$ & \\
\hline$A_{1}$ & 0.47 & 0.47 & 0.19 & 0.47 & 0.55 & 0.57 & 0.87 & 0.9 & 0.56 \\
\hline $\mathrm{A}_{2}$ & 0.18 & 0.15 & 0.18 & 0.18 & 0.29 & 0.07 & 0.33 & 0.71 & 0.29 \\
\hline$A_{3}$ & 0.36 & 0.38 & 0.63 & 0.36 & 0.15 & 0.35 & 0.67 & 0.29 & 0.38 \\
\hline Expert 2 & \multicolumn{2}{|c|}{$\mathrm{C}_{1}(0.08)$} & \multicolumn{2}{|c|}{$\mathrm{C}_{2}(\mathbf{0 . 6 0 )}$} & \multicolumn{2}{|c|}{$\mathrm{C}_{3}(0.05)$} & \multicolumn{2}{|c|}{$\mathrm{C}_{4}(0.28)$} & $\mathbf{W}$ \\
\hline & $\mathrm{C}_{11}(0.82)$ & $\mathrm{C}_{12}(0.18)$ & $\mathrm{C}_{21}(0.11)$ & $\mathrm{C}_{22}(0.89)$ & $\mathrm{C}_{31}(0.89)$ & $\mathrm{C}_{32}(0.11)$ & $\mathrm{C}_{41}(0.71)$ & $\mathrm{C}_{42}(0.29)$ & \\
\hline$A_{1}$ & 0.21 & 0.11 & 0.37 & 0.28 & 0.07 & 0.16 & 0.23 & 0.38 & 0.27 \\
\hline$A_{2}$ & 0.68 & 0.72 & 0.56 & 0.46 & 0.53 & 0.75 & 0.77 & 0.67 & 0.56 \\
\hline$A_{3}$ & 0.11 & 0.17 & 0.07 & 0.26 & 0.41 & 0.09 & 0.23 & 0.33 & 0.24 \\
\hline \multirow[t]{2}{*}{ Expert 3} & \multicolumn{2}{|c|}{$\mathrm{C}_{1}(\mathbf{0 . 0 8 )}$} & \multicolumn{2}{|c|}{$\mathrm{C}_{2}(0.66)$} & \multicolumn{2}{|c|}{$\mathrm{C}_{3}(0.05)$} & \multicolumn{2}{|c|}{$\mathrm{C}_{4}(0.21)$} & $\mathbf{W}$ \\
\hline & $\mathrm{C}_{11}(0.89)$ & $\mathrm{C}_{12}(0.11)$ & $\mathrm{C}_{21}(0.18)$ & $\mathrm{C}_{22}(0.82)$ & $\mathrm{C}_{31}(0.87)$ & $\mathrm{C}_{32}(0.13)$ & $\mathrm{C}_{41}(0.41)$ & $\mathrm{C}_{42}(0.59)$ & \\
\hline$A_{1}$ & 0.17 & 0.11 & 0.38 & 0.28 & 0.07 & 0.19 & 0.25 & 0.44 & 0.29 \\
\hline$A_{2}$ & 0.72 & 0.72 & 0.54 & 0.5 & 0.53 & 0.71 & 0.71 & 0.7 & 0.57 \\
\hline$A_{3}$ & 0.11 & 0.17 & 0.08 & 0.22 & 0.41 & 0.09 & 0.29 & 0.3 & 0.22 \\
\hline
\end{tabular}

\begin{tabular}{lccc}
\hline & E1 & E2 & E3 \\
\hline Scenario1 & $40 \%$ & $30 \%$ & $30 \%$ \\
\hline Scenario2 & $30 \%$ & $40 \%$ & $30 \%$ \\
\hline Scenario3 & $30 \%$ & $30 \%$ & $40 \%$ \\
\hline Scenario4 & $33.33 \%$ & $33.33 \%$ & $33.33 \%$ \\
\hline
\end{tabular}

Table 7. Ranking scores with respect to each expert 
560 C. Kahraman et al. Fuzzy multi-criteria and multi-experts evaluation of government investments...

Continued Table 7

\begin{tabular}{|c|c|c|c|c|c|c|c|c|c|}
\hline $\begin{array}{l}\text { Scenarios } \\
\text { Ranking }\end{array}$ & \multicolumn{9}{|c|}{ Criteria (Weights) } \\
\hline Scenario 1 & \multicolumn{2}{|c|}{$\mathrm{C}_{1}(0.10)$} & \multicolumn{2}{|c|}{$\mathrm{C}_{2}(0.59)$} & \multicolumn{2}{|c|}{$\mathrm{C}_{3}(0.05)$} & \multicolumn{2}{|c|}{$\mathrm{C}_{4}(0.25)$} & $\mathrm{W}$ \\
\hline & $\mathrm{C}_{11}(0.86)$ & $\mathrm{C}_{12}(0.14)$ & $\mathrm{C}_{21}(0.14)$ & $\mathrm{C}_{22}(0.86)$ & $\mathrm{C}_{31}(0.88)$ & $\mathrm{C}_{32}(0.12)$ & $\mathrm{C}_{41}(0.45)$ & $\mathrm{C}_{42}(0.55)$ & \\
\hline$A_{1}$ & 0.3 & 0.25 & 0.3 & 0.35 & 0.26 & 0.33 & 0.49 & 0.6 & 0.39 \\
\hline $\mathrm{A}_{2}$ & 0.49 & 0.49 & 0.4 & 0.36 & 0.43 & 0.47 & 0.58 & 0.7 & 0.45 \\
\hline $\mathrm{A}_{3}$ & 0.21 & 0.25 & 0.3 & 0.29 & 0.31 & 0.19 & 0.42 & 0.3 & 0.30 \\
\hline Scenario 2 & \multicolumn{2}{|c|}{$\mathrm{C}_{1}(0.10)$} & \multicolumn{2}{|c|}{$\mathrm{C}_{2}(0.60)$} & \multicolumn{2}{|c|}{$\mathrm{C}_{3}(0.05)$} & \multicolumn{2}{|c|}{$\mathrm{C}_{4}(0.25)$} & $\mathrm{W}$ \\
\hline & $\mathrm{C}_{11}(0.86)$ & $\mathrm{C}_{12}(0.14)$ & $\mathrm{C}_{21}(0.13)$ & $\mathrm{C}_{22}(0.87)$ & $\mathrm{C}_{31}(0.88)$ & $\mathrm{C}_{32}(0.12)$ & $\mathrm{C}_{41}(0.49)$ & $\mathrm{C}_{42}(0.51)$ & \\
\hline A1 & 0.27 & 0.22 & 0.32 & 0.34 & 0.21 & 0.29 & 0.43 & 0.55 & 0.36 \\
\hline A2 & 0.54 & 0.55 & 0.44 & 0.39 & 0.46 & 0.54 & 0.62 & 0.69 & 0.48 \\
\hline A3 & 0.18 & 0.23 & 0.24 & 0.28 & 0.33 & 0.17 & 0.38 & 0.31 & 0.28 \\
\hline Scenario 3 & \multicolumn{2}{|c|}{$\mathrm{C}_{1}(0.10)$} & \multicolumn{2}{|c|}{$\mathrm{C}_{2}(0.61)$} & \multicolumn{2}{|c|}{$\mathrm{C}_{3}(0.05)$} & \multicolumn{2}{|c|}{$\mathrm{C}_{4}(0.24)$} & $\mathrm{W}$ \\
\hline & $\mathrm{C}_{11}(0.87)$ & $\mathrm{C}_{12}(0.13)$ & $\mathrm{C}_{21}(0.14)$ & $\mathrm{C}_{22}(0.86)$ & $\mathrm{C}_{31}(0.88)$ & $\mathrm{C}_{32}(0.12)$ & $\mathrm{C}_{41}(0.46)$ & $\mathrm{C}_{42}(0.54)$ & \\
\hline$A_{1}$ & 0.27 & 0.22 & 0.32 & 0.34 & 0.21 & 0.3 & 0.43 & 0.56 & 0.36 \\
\hline $\mathrm{A}_{2}$ & 0.55 & 0.55 & 0.44 & 0.39 & 0.46 & 0.53 & 0.61 & 0.7 & 0.48 \\
\hline $\mathrm{A}_{3}$ & 0.18 & 0.23 & 0.24 & 0.27 & 0.33 & 0.17 & 0.39 & 0.3 & 0.28 \\
\hline Scenario 4 & \multicolumn{2}{|c|}{$\mathrm{C}_{1}(0.10)$} & \multicolumn{2}{|c|}{$\mathrm{C}_{2}(0.60)$} & \multicolumn{2}{|c|}{$\mathrm{C}_{3}(0.05)$} & \multicolumn{2}{|c|}{$\mathrm{C}_{4}(0.25)$} & $\mathrm{W}$ \\
\hline & $\mathrm{C}_{11}(0.86)$ & $\mathrm{C}_{12}(0.14)$ & $\mathrm{C}_{21}(0.14)$ & $\mathrm{C}_{22}(0.86)$ & $\mathrm{C}_{31}(0.88)$ & $\mathrm{C}_{32}(0.12)$ & $\mathrm{C}_{41}(0.47)$ & $\mathrm{C}_{42}(0.53)$ & \\
\hline$A_{1}$ & 0.28 & 0.23 & 0.31 & 0.34 & 0.23 & 0.31 & 0.45 & 0.57 & 0.37 \\
\hline $\mathrm{A}_{2}$ & 0.53 & 0.53 & 0.43 & 0.38 & 0.45 & 0.51 & 0.6 & 0.7 & 0.47 \\
\hline $\mathrm{A}_{3}$ & 0.19 & 0.24 & 0.26 & 0.28 & 0.32 & 0.18 & 0.4 & 0.3 & 0.29 \\
\hline
\end{tabular}

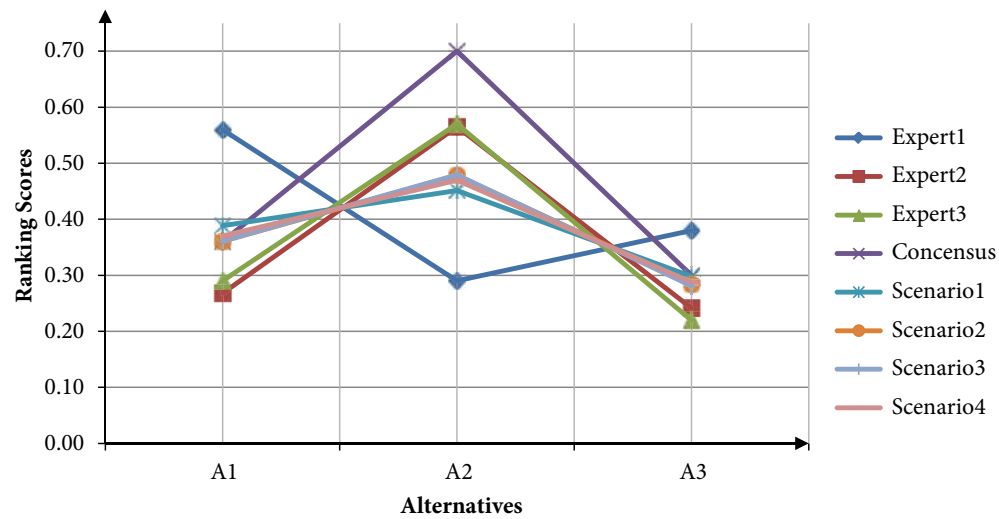

Fig. 3. Rankings of alternatives obtained by Fuzzy AHP with respect to expert preferences and weighting scenarios 
According to Fig. 3, the ranking of alternatives are all the same except Expert 1's preferences. According to Expert 1, the best alternative is A1. However, the best alternative is A2 with respect to the joint decisions obtained by both consensus and weighting scenarios.

\subsection{Fuzzy TOPSIS}

Since it is computationally simple and effective, we preferred the TOPSIS method, which is one of the most used multi-criteria methods. Hwang and Yoon (1981) introduced the TOPSIS method to the literature. This method was extended to a fuzzy environment by Chen and Hwang (1992) in order to cope with uncertainties in decision making problems. The essence of the TOPSIS is to select an alternative which has the shortest distance from the positive-ideal solution and the longest distance from the negative-ideal solution. Krohling and Campanharo (2011) firstly describe TOPSIS. Secondly, its expansion known as fuzzy TOPSIS to handle uncertain data is presented. Next, based on fuzzy TOPSIS they propose a fuzzy TOPSIS for group decision making, which is applied to evaluate the ratings of response alternatives to a simulated oil spill. Paksoy et al. (2012) develop the organization strategy of distribution channel management using fuzzy analytic hierarchy process and hierarchical fuzzy TOPSIS for an edible-vegetable oils manufacturer firm operating in Turkey. Kutlu and Ekmekcioglu (2012) allow experts to use linguistic variables for determining severity, occurrence, and detectability for FMEA by applying fuzzy TOPSIS integrated with fuzzy AHP.

The fuzzy TOPSIS method is summarized by six steps (Chen 2000). An illustration of calculation procedure for Expert-1 (E1)'s preferences is given in the following:

Step 1. Evaluation of alternatives and determination of criteria weights: Evaluation is given in Table A4 in the Appendix. The weights obtained by fuzzy AHP method are used in the fuzzy TOPSIS.

Step 2. Normalization of the obtained scores (Table 8).

To avoid the complicated normalization formula used in classical TOPSIS, we use linear scale transformation as follows:

$$
r_{i j}=\left\{\begin{array}{l}
x_{i j} / x_{j}^{*}, \forall j, x_{j} \text { is a benefit attribute } \\
x_{j}^{-} / x_{i j}, \forall j, x_{j} \text { is a cost attribute }
\end{array} .\right.
$$

By applying Eq. (6), we can write the normalized decision matrix $(D)$ as:

$$
D=\left[\begin{array}{ccccc}
r_{11} & \cdots & r_{1 j} & \cdots & r_{1 n} \\
\vdots & \ddots & \vdots & \ddots & \vdots \\
r_{i 1} & \cdots & r_{i j} & \cdots & r_{i n} \\
\vdots & \ddots & \vdots & \ddots & \vdots \\
r_{m 1} & \cdots & r_{m j} & \cdots & r_{m n}
\end{array}\right]
$$


562 C. Kahraman et al. Fuzzy multi-criteria and multi-experts evaluation of government investments...

Let $x_{j}^{-}=\left(a_{i j}, b_{i j}, c_{i j}, d_{i j}\right)$ and $x_{j}^{*}=\left(a_{j}^{*}, b_{j}^{*}, c_{j}^{*}, d_{j}^{*}\right)$ we have:

$$
r_{i j}=\left\{\begin{array}{l}
x_{i j}(\div) x_{j}^{*}=\left(\frac{a_{i j}}{d_{j}^{*}}, \frac{b_{i j}}{c_{j}^{*}}, \frac{c_{i j}}{b_{j}^{*}}, \frac{d_{i j}}{a_{j}^{*}}\right), \text { for benefit attributes } \\
x_{j}^{-}(\div) x_{i j}=\left(\frac{a_{i}^{-}}{d_{i j}}, \frac{b_{i}^{-}}{c_{i j}}, \frac{c_{i}^{-}}{b_{i j}}, \frac{d_{i}^{-}}{a_{i j}}\right), \text { for cost attributes }
\end{array}\right.
$$

Step 3. Construction of the weighted normalized fuzzy decision matrix (Table 8).

This matrix is obtained using:

$$
v_{i j}=r_{i j} w_{j}, \forall i, j
$$

When both $r_{i j}$ and $w_{j}$ are crisp, $v_{i j}$ is crisp; when either $r_{i j}$ or $w_{j}$ (or both) are fuzzy, Eq. (9) may be replaced by the following fuzzy operations:

$$
v_{i j}=r_{i j}(.) w_{j}=\left\{\begin{array}{l}
\left(\frac{a_{i j}}{d_{j}^{*}} \alpha_{j}, \frac{b_{i j}}{c_{j}^{*}} \beta_{j}, \frac{c_{i j}}{b_{j}^{*}} \gamma_{j}, \frac{d_{i j}}{a_{j}^{*}} \delta_{j}\right), \text { for benefit attributes } \\
\left(\frac{a_{i}^{-}}{d_{i j}} \alpha_{j}, \frac{b_{i}^{-}}{c_{i j}} \beta_{j}, \frac{c_{i}^{-}}{b_{i j}} \gamma_{j}, \frac{d_{i}^{-}}{a_{i j}} \delta\right), \text { for cost attributes }
\end{array}\right.
$$

The result of Eq. (10) can be summarized as:

$$
V=\left[\begin{array}{ccccc}
v_{11} & \cdots & v_{1 j} & \cdots & v_{1 n} \\
\vdots & \ddots & \vdots & \ddots & \vdots \\
v_{i 1} & \cdots & v_{i j} & \cdots & v_{i n} \\
\vdots & \ddots & \vdots & \ddots & \vdots \\
v_{m 1} & \cdots & v_{m j} & \cdots & v_{m n}
\end{array}\right] .
$$

Step 4. Calculation of the distances of each alternative from fuzzy positive-ideal solution (FPIS, $A^{*}$ ) and fuzzy negative-ideal solution (FNIS, $A^{-}$), respectively (Table 9):

$$
\begin{aligned}
& A^{\star}=\left[v_{1}^{*}, \ldots, v_{n}^{*}\right] ; \\
& A^{-}=\left[v_{1}^{-}, \ldots, v_{n}^{-}\right],
\end{aligned}
$$

where: $v_{j}^{*}=\max v_{i j}$ and $v_{j}^{-}=\min v_{i j}$.

For crisp data, $v_{j}^{*}$ and $v_{j}^{-}$are obtained straight forward. For fuzzy data, $v_{j}^{*}$ and $v_{j}^{-}$may be obtained through some ranking procedures.

Step 5. Calculation of closeness coefficients $\left(C C_{i}\right)$.

We first obtain the separation measures $S_{i}^{*}$ and $S_{i}^{-}$. In the classical case, separation measures are defined as:

$$
S_{i}^{*}=\sum_{j=1}^{n} D_{i j}^{*}, i=1, \ldots, m
$$


and

$$
S_{i}^{-}=\sum_{j=1}^{n} D_{i j}^{-}, i=1, \ldots, m .
$$

For crisp data, the difference measures $D_{i j}^{*}$ and $D_{i j}^{-}$are given as:

$$
\begin{aligned}
& D_{i j}^{*}=\left|v_{i j}-v_{j}^{*}\right| ; \\
& D_{i j}^{-}=\left|v_{i j}-v_{j}^{-}\right| .
\end{aligned}
$$

For fuzzy data:

$$
D_{i j}^{*}=1-\left\{\sup _{x}\left[\mu_{v_{i j}}(x) \wedge \mu_{v_{j}^{*}}(x)\right]\right\}=1-L_{i j}, \forall j, i,
$$

where: $L_{i j}$ is the highest degree of similarity of $v_{i j}$ and $v_{j}^{*}$.

The difference between $\mu_{v_{i j}}(x)$ and $\mu_{v_{i j}^{-}}(x)$ is defined as:

$$
D_{i j}^{-}=1-\left\{\sup _{x}\left[\mu_{v_{i j}}(x) \wedge \mu_{v_{j}^{-}}(x)\right]\right\}=1-L_{i j}, \forall j, i .
$$

Note that $D_{i j}^{*}$ and $D_{i j}^{-}$are crisp numbers.

Since $S_{i}^{*}$ and $S_{i}^{-}$are crisp numbers, they can be combined:

$$
C C_{i}=\frac{S_{i}^{-}}{\left(S_{i}^{*}+S_{i}^{-}\right)} .
$$

The alternatives are ranked in descending order of the $C C_{i}$ index.

The same calculation procedure is applied to all the experts' preferences and scenarios given in Table 6. The calculated closeness coefficients are presented in Table 9 and the results are illustrated in Fig. 4. According to Fig. 4, the results are similar to Fig. 3 except for Scenario 1. In the first application, there is a little difference between A2 and A1.

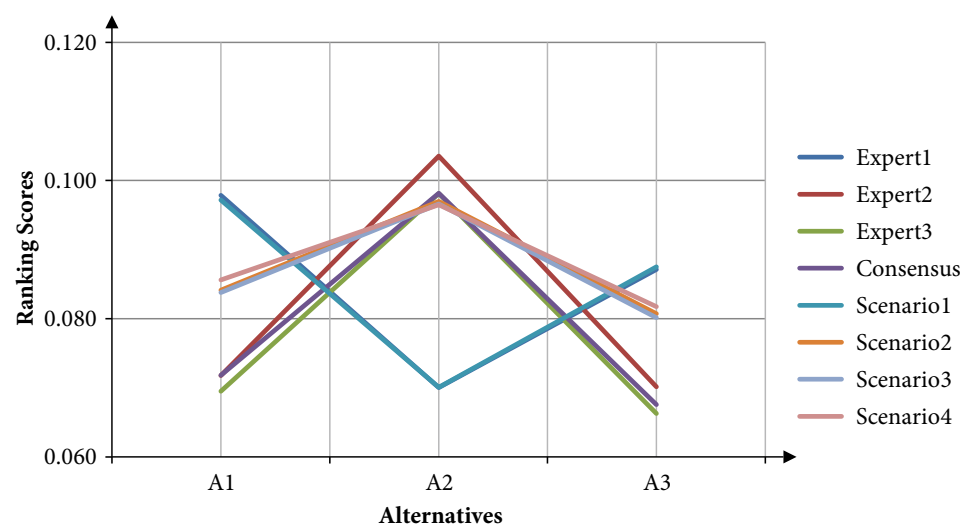

Fig. 4. Ranking scores for alternatives obtained by Fuzzy TOPSIS with respect to the expert preferences and weighting scenarios. 
564 C. Kahraman et al. Fuzzy multi-criteria and multi-experts evaluation of government investments...

Table 8. Normalized and weighted matrix

\begin{tabular}{|c|c|c|c|c|c|c|c|}
\hline \multicolumn{2}{|c|}{$\mathrm{C}_{1}(0.13)$} & \multicolumn{2}{|c|}{$\mathrm{C}_{2}(0.54)$} & \multicolumn{2}{|c|}{$\mathrm{C}_{3}(0.06)$} & \multicolumn{2}{|c|}{$\mathrm{C}_{4}(0.26)$} \\
\hline $\mathrm{C}_{11}(0.87)$ & $\mathrm{C}_{12}(0.13)$ & $\mathrm{C}_{21}(0.13)$ & $\mathrm{C}_{22}(0.87)$ & $\mathrm{C}_{31}(0.87)$ & $\mathrm{C}_{32}(0.13)$ & $\mathrm{C}_{41}(29)$ & $\mathrm{C}_{42}(0.71)$ \\
\hline $\mathbf{A}_{1} \quad(7,10,10)$ & $(7,10,10)$ & $(2.5,5,7.5)$ & $(5,7.5,10)$ & $(7,10,10)$ & $(5,7.5,10)$ & $(7,10,10)$ & $(5,7.5,10)$ \\
\hline $\begin{array}{ll}\mathbf{A}_{2} & (2.5,5,7.5) \\
\end{array}$ & $(0,2.5,5)$ & $(5,7.5,10)$ & $(2.5,5,7.5)$ & $(7,10,10)$ & $(0,2.5,5)$ & $(2.5,5,7.5)$ & $(2.5,5,7.5)$ \\
\hline $\mathbf{A}_{3} \quad(5,7.5,10)$ & $(2.5,5,7.5)$ & $(2.5,5,7.5)$ & $(5,7.5,10)$ & $(2.5,5,7.5)$ & $(2.5,5,7.5)$ & $(7,10,10)$ & $(2.5,5,7.5)$ \\
\hline \multicolumn{8}{|c|}{ Normalized Matrix } \\
\hline $\mathbf{A}_{1} \quad(0.7,1,1)$ & $(0.7,1,1)$ & $(0.25,0.5,0.75)$ & $(0.5,0.75,1)$ & $(0.7,1,1)$ & $(0.5,0.75,1)$ & $(0.7,1,1)$ & $(0.5,0.75,1)$ \\
\hline $\begin{array}{c}\mathbf{A}_{2} \quad(0.25,0.5, \\
0.75)\end{array}$ & $\begin{array}{c}(0,0.25 \\
0.5)\end{array}$ & $(0.5,0.75,1)$ & $\begin{array}{c}(0.25,0.5 \\
0.75)\end{array}$ & $(0.7,1,1)$ & $\begin{array}{c}(0,0.25 \\
0.5)\end{array}$ & $\begin{array}{c}(0.25,0.5 \\
0.75)\end{array}$ & $\begin{array}{l}(0.25,0.5 \\
0.75)\end{array}$ \\
\hline $\mathbf{A}_{3}(0.5,0.75,1)$ & $\begin{array}{c}(0.25,0.5 \\
0.75)\end{array}$ & $(0.25,0.5,0.75)$ & $(0.5,0.75,1)$ & $\begin{array}{c}(0.25,0.5 \\
0.75)\end{array}$ & $\begin{array}{c}(0.25,0.5 \\
0.75)\end{array}$ & $(0.7,1,1)$ & $\begin{array}{c}(0.25,0.5 \\
0.75)\end{array}$ \\
\hline \multicolumn{8}{|c|}{ Weighted normalized matrix } \\
\hline $\begin{array}{c}A_{1}(0.079,0.113 \\
0.113)\end{array}$ & $\begin{array}{c}(0.012,0.017, \\
0.017)\end{array}$ & $\begin{array}{c}(0.017,0.035 \\
0.052)\end{array}$ & $\begin{array}{c}(0.235,0.353, \\
0.471)\end{array}$ & $\begin{array}{c}(0.035,0.051, \\
0.051)\end{array}$ & $\begin{array}{c}(0.004, \\
0.006,0.007)\end{array}$ & $\begin{array}{c}(0.053,0.076, \\
0.076)\end{array}$ & $\begin{array}{c}(0.092,0.138, \\
0.184)\end{array}$ \\
\hline $\begin{array}{c}\mathbf{A}_{2}(0.028,0.057 \\
0.085)\end{array}$ & $\begin{array}{c}(0,0.004 \\
0.008)\end{array}$ & $\begin{array}{c}(0.035,0.052 \\
0.069)\end{array}$ & $\begin{array}{c}(0.118,0.235 \\
0.353)\end{array}$ & $\begin{array}{c}(0.035,0.051, \\
0.051)\end{array}$ & $\begin{array}{c}(0,0.002 \\
0.004)\end{array}$ & $\begin{array}{c}(0.019,0.038, \\
0.057)\end{array}$ & $\begin{array}{c}(0.046,0.092, \\
0.138)\end{array}$ \\
\hline $\begin{array}{c}A_{3}(0.057,0.085 \\
0.113)\end{array}$ & $\begin{array}{l}.004,0.008, \\
0.012)\end{array}$ & $\begin{array}{c}(0.017,0.035 \\
0.052)\end{array}$ & $\begin{array}{c}(0.235,0.353 \\
0.471)\end{array}$ & $\begin{array}{c}0.013,0.025, \\
0.038)\end{array}$ & $\begin{array}{c}(0.002, \\
0.004,0.006)\end{array}$ & $\begin{array}{c}(0.053,0.076, \\
0.076)\end{array}$ & $\begin{array}{c}(0.046,0.092, \\
0.138)\end{array}$ \\
\hline
\end{tabular}

The normalized matrix given in Table 8 is calculated by dividing each value to 10 which is the biggest upper value in the evaluation matrix. An illustrative example is given below for A1 under C11:

$$
\begin{aligned}
& \tilde{A}_{1}^{w}=w_{C 1}{ }^{\star} w_{C 11}{ }^{\star} \tilde{A}_{1} ; \\
& \tilde{A}_{1}^{w}=0.13^{\star} 0.87^{\star}(0.7,1,1) ; \\
& \tilde{A}_{1}^{w}=(0.079,0.113,0.113) .
\end{aligned}
$$

An illustrative example is given for the value given in the first row and first column of Table 9 as follows:

$$
\begin{aligned}
& \text { FPIS, } \mathrm{A}_{11}^{*}=\frac{1}{3}\left[(0.079-1)^{2}+(0.113-1)^{2}+(0.113-1)^{2}\right]^{1 / 2} ; \\
& \text { FPIS, } \mathrm{A}_{11}^{*}=0.519 .
\end{aligned}
$$

Table 9. Distances of each alternative from fuzzy positive-ideal solution and fuzzy negative-ideal solution

\begin{tabular}{ccccccccccc}
\hline \multicolumn{10}{c}{ FPIS, A } \\
\hline $\mathbf{A}_{1}$ & 0.519 & 0.569 & 0.557 & 0.378 & 0.551 & 0.574 & 0.538 & 0.498 & 4.183 \\
\hline $\mathbf{A}_{2}$ & 0.545 & 0.575 & 0.547 & 0.445 & 0.551 & 0.576 & 0.555 & 0.525 & 4.320 \\
\hline $\mathbf{A}_{3}$ & 0.528 & 0.573 & 0.557 & 0.378 & 0.563 & 0.575 & 0.538 & 0.525 & 4.237 & \\
\hline \multicolumn{1}{c}{} & \multicolumn{3}{c}{ FNIS, A $^{-}$} \\
\hline $\mathbf{A}_{1}$ & 0.060 & 0.009 & 0.022 & 0.211 & 0.027 & 0.003 & 0.040 & 0.082 & 0.454 & 0.098 \\
\hline $\mathbf{A}_{2}$ & 0.035 & 0.003 & 0.031 & 0.147 & 0.027 & 0.001 & 0.024 & 0.057 & 0.325 & 0.070 \\
\hline $\mathbf{A}_{3}$ & 0.051 & 0.005 & 0.022 & 0.211 & 0.016 & 0.002 & 0.040 & 0.057 & 0.404 & 0.087 \\
\hline
\end{tabular}


$C C^{*}(4.183)$ s obtained by taking sum of the related row. The value given in the first row and tenth column of Table 9 as follows:

FNIS, $\mathrm{A}^{-}=\frac{1}{3}\left[0.079^{2}+0.113^{2}+0.113^{2}\right]^{1 / 2} ;$

FNIS, $\mathrm{A}^{-}=0.06$.

$C C^{-}(0.454)$ is obtained by taking sum of the related row.

An illustrative example of $C C_{i}$ is given below:

$$
\begin{aligned}
& C C_{1}=\frac{F N I S, A_{1 i}^{-}}{F N I S, A_{1 i}^{*}+F N I S, A_{1 i}^{-}} ; \\
& C C_{1}=\frac{0.454}{4.183+0.454} ; \\
& C C_{1}=0.098 .
\end{aligned}
$$

\section{Conclusions}

Educational investments are performed within the framework of an investment program. The cost of higher education to government is the opportunity cost of public expenditure on it. Investment in higher education yields high return to individuals, society and the government. It may be possible government implementing policies to increase the investments in higher education. Creating jobs, skills and markets for products and services and supporting research and technological development have an important priority. Government policy should be concerned with the marginal rate of return when deciding whether to increase their expenditure on higher education.

We considered the investment in higher education as a multi-criteria problem including many conflicting attributes. The uncertainty has been handled by the fuzzy sets. The obtained results by fuzzy AHP were compared by the fuzzy TOPSIS method's results. The sensitivity analysis shows that the ranking of the alternatives is not sensitive to the chances in the criteria weights.

Our research indicates that the public sector in Turkey has a larger priority with respect to the private sector. Investments to technology parks should be preferred to investments in new laboratories. Turkish Government should give more importance to international competition than national competition and also care about collaboration among institutions.

For further research, the other fuzzy decision-making approaches such as VIKOR, ELECTRE, PROMETHEE, and ANP can be used and their results can be compared with the results of this paper. Our model can be applied to the other regions of Turkey, so that regional differences in higher education investments can be analysed. 


\section{References}

Andersson, R.; Quigley, J. M.; Wilhelmsson, M. 2009. Urbanization, productivity, and innovation: evidence from investment in higher education, Journal of Urban Economics 66(1): 2-15. http://dx.doi.org/10.1016/j.jue.2009.02.004

Arcalean, C.; Schiopu, I. 2010. Public versus private investment and growth in a hierarchical education system, Journal of Economic Dynamics \& Control 34(4): 604-622. http://dx.doi.org/10.1016/j.jedc.2009.11.006

Azadeh, A.; Osanloo, M.; Ataei, M. 2010. A new approach to mining method selection based on modifying the Nicholas technique, Applied Soft Computing 10(4): 1040-1061. http://dx.doi.org/10.1016/j.asoc.2009.09.002

Bennell, P.; Pearce, T. 2003. The internationalisation of higher education: exporting education to developing and transitional economies, International Journal of Educational Development 23(2): 215-232. http://dx.doi.org/10.1016/S0738-0593(02)00024-X

Bennell, P.; Pearce, T. 2012. The internationalisation of higher education: exporting education to developing and transitional economies: IDS working paper 75, Institute of Development Studies.

Buckley, J. J. 1985. Fuzzy hierarchical analysis, Fuzzy Sets and Systems 34(2): 187-195. http://dx.doi.org/10.1016/0165-0114(90)90158-3

Cebeci, U. 2009. Fuzzy AHP-based decision support system for selecting ERP systems in textile industry by using balanced scorecard, Expert Systems with Applications 36(5): 8900-8909. http://dx.doi.org/10.1016/j.eswa.2008.11.046

Celik, M.; Kandakoglu, A.; Er, I. D. 2009. Structuring fuzzy integrated multi-stages evaluation model on academic personnel recruitment in MET institutions, Expert Systems with Applications 36(2): 6918-6927. http://dx.doi.org/10.1016/j.eswa.2008.08.057

Chen, S. J.; Hwang, C. L. 1992. Fuzzy multi attribute decision making: methods and applications. New York: Springer-Verlag. http://dx.doi.org/10.1007/978-3-642-46768-4

Chen, T.-C. 2000. Extensions of the TOPSIS for group decision-making under fuzzy environment, Fuzzy Sets and Systems 114(1): 1-9. http://dx.doi.org/10.1016/S0165-0114(97)00377-1

Chen, V. Y. C.; Lien, H.-P.; Liuc, C.-H.; Lioud, J. J. H.; Tzeng, G.-H.; Yang, L.-S. 2011. Fuzzy MCDM approach for selecting the best environment-watershed plan, Applied Soft Computing 11(1): 265-275. http://dx.doi.org/10.1016/j.asoc.2009.11.017

Gradstein, M.; Justman, M. 1995. Competitive investment in higher education: the need for policy coordination, Economics Letters 47(3-4): 393-400. http://dx.doi.org/10.1016/0165-1765(94)00554-F

Hsieh, T. Y.; Lu, S. T.; Tzeng, G. T. 2004. Fuzzy MCDM approach for planning and design tenders selection in public office buildings, International Journal of Project Management 22(7): 573-584. http://dx.doi.org/10.1016/j.ijproman.2004.01.002

Hsu, W.-K. K. 2012. Ports' service attributes for ship navigation safety, Safety Science 50(2): 244-252. http://dx.doi.org/10.1016/j.ssci.2011.08.057

Hwang, C. L.; Yoon, K. 1981. Multiple attribute decision making methods and applications. New York: Springer-Verlag. http://dx.doi.org/10.1007/978-3-642-48318-9

Jaskowski, P.; Biruk, S.; Bucon, R. 2010. Assessing contractor selection criteria weights with fuzzy AHP method application in group decision environment, Automation in Construction 19(2): 120-126. http://dx.doi.org/10.1016/j.autcon.2009.12.014

Javanbarg, M. B.; Scawthorn, C.; Kiyono, J.; Shahbodaghkhan, B. 2012. Fuzzy AHP-based multicriteria decision making systems using particle swarm optimization, Expert Systems with Applications 39(1): 960-966. http://dx.doi.org/10.1016/j.eswa.2011.07.095 
Kahraman, C.; Çebi, S. 2009. A new multi-attribute decision making method: hierarchical fuzzy axiomatic design, Expert Systems with Applications 36(3): 4848-4861.

http://dx.doi.org/10.1016/j.eswa.2008.05.041

Kaya, T.; Kahraman, C. 2011. An integrated fuzzy AHP-ELECTRE methodology for environmental impact assessment, Expert Systems with Applications 38(7): 8553-8562. http://dx.doi.org/10.1016/j.eswa.2011.01.057

Krohling, R. A.; Campanharo, V. C. 2011. Fuzzy TOPSIS for group decision making: a case study for accidents with oil spill in the sea, Expert Systems with Applications 38(4): 4190-4197. http://dx.doi.org/10.1016/j.eswa.2010.09.081

Kutlu, A. C.; Ekmekcioglu, M. 2012. Fuzzy failure modes and effects analysis by using fuzzy TOPSIS-based fuzzy AHP, Expert Systems with Applications 39(1): 61-67. http://dx.doi.org/10.1016/j.eswa.2011.06.044

Lavasani, S. M. M.; Yang, Z.; Finlay, J.; Wang, J. 2011. Fuzzy risk assessment of oil and gas offshore wells, Process Safety and Environmental Protection 89(5): 277-294. http://dx.doi.org/10.1016/j.psep.2011.06.006

Lo, Y.-F.; Wen, M.-H. 2010. A fuzzy-AHP-based technique for the decision of design feature selection in Massively Multiplayer Online Role-Playing Game development, Expert Systems with Applications 37(12): 8685-8693. http://dx.doi.org/10.1016/j.eswa.2010.06.059

Opricovic, S.; Tzeng, G. H. 2004. Compromise solution by MCDM methods: a comparative analysis of VIKOR and TOPSIS, European Journal of Operational Research 156(2): 445-455. http://dx.doi.org/10.1016/S0377-2217(03)00020-1

Paksoy, T.; Pehlivan, N. Y.; Kahraman, C. 2012. Organizational strategy development in distribution channel management using fuzzy AHP and hierarchical fuzzy TOPSIS, Expert Systems with Applications 39(3): 2822-2841. http://dx.doi.org/10.1016/j.eswa.2011.08.142

Pan, N. F. 2009. Selecting an appropriate excavation construction method based on qualitative assessments, Expert Systems with Applications 36(3): 5481-5490. http://dx.doi.org/10.1016/j.eswa.2008.06.097

Tiryaki, F.; Ahlatcioglu, B. 2009. Fuzzy portfolio selection using fuzzy analytic hierarchy process, Information Sciences 179(1-2): 53-69. http://dx.doi.org/10.1016/j.ins.2008.07.023

Voon, J. P. 2001. Measuring social returns to higher education investments in Hong Kong: production function approach, Economics of Education Review 20(5): 503-510. http://dx.doi.org/10.1016/S0272-7757(00)00021-2

Wei, G. 2011. FIOWHM operator and its application to multiple attribute group decision making, Expert Systems with Applications 38(4): 2984-2989. http://dx.doi.org/10.1016/j.eswa.2010.08.087

Zadeh, L. A. 1965. Fuzzy sets, Information Control 8(3): 338-353.

http://dx.doi.org/10.1016/S0019-9958(65)90241-X 
568 C. Kahraman et al. Fuzzy multi-criteria and multi-experts evaluation of government investments...

\section{APPENDIX}

Table A1. Pairwise matrices of Expert 1

\begin{tabular}{|c|c|c|c|c|c|c|c|c|c|c|c|c|c|c|c|c|c|c|c|}
\hline $\mathrm{C}$ & $\mathrm{Cl}$ & $\mathrm{C} 2$ & $\mathrm{C3}$ & $\mathrm{C} 4$ & & $\mathrm{C1}$ & C11 & $\mathrm{C} 12$ & $\mathrm{C} 2$ & C21 & $\mathrm{C22}$ & & C3 & C31 & C32 & & $\mathrm{C} 4$ & C41 & $\mathrm{C} 42$ \\
\hline $\mathrm{C1}$ & & 1/Wk & $\mathrm{Wk}$ & $1 / \mathrm{Es}$ & & C11 & & Vs & C21 & & $1 / \mathrm{Vs}$ & & C31 & & Vs & & C41 & & $1 / \mathrm{Wk}$ \\
\hline$\overline{\mathrm{C} 2}$ & & & Vs & Es & & $\mathrm{C} 12$ & & & $\mathrm{C22}$ & & & & C32 & & & & C42 & & \\
\hline $\mathrm{C3}$ & & & & $1 /$ Es & & & & & & & & & & & & & & & \\
\hline \multicolumn{20}{|l|}{$\mathrm{C4}$} \\
\hline C11 & A1 & A2 & A3 & & $\mathrm{C} 12$ & A1 & A2 & A3 & C21 & A1 & A2 & A3 & & $\mathrm{C22}$ & A1 & A2 & A3 & & \\
\hline A1 & & $\mathrm{Wk}$ & $\mathrm{Eq}$ & & A1 & & $\mathrm{Eq}$ & Wk & A1 & & $1 / \mathrm{Eq}$ & $1 / \mathrm{Wk}$ & & A1 & & Wk & $\mathrm{Eq}$ & & \\
\hline A2 & & & 1/Wk & & A2 & & & $1 / \mathrm{Es}$ & A2 & & & $1 /$ Es & & A2 & & & 1/Wk & & \\
\hline A3 & & & & & A3 & & & & A3 & & & & & A3 & & & & & \\
\hline C31 & A1 & A2 & A3 & & C32 & A1 & A2 & A3 & C41 & A1 & A2 & A3 & & $\mathrm{C} 42$ & A1 & A2 & A3 & & \\
\hline A1 & & $\mathrm{Eq}$ & Es & & A1 & & Es & $\mathrm{Wk}$ & A1 & & $\mathrm{Wk}$ & $\mathrm{Eq}$ & & A1 & & Wk & $\mathrm{Eq}$ & & \\
\hline A2 & & & $\mathrm{Eq}$ & & A2 & & & $1 / \mathrm{Vs}$ & A2 & & & $1 / \mathrm{Wk}$ & & A2 & & & Es & & \\
\hline A3 & & & & & A3 & & & & A3 & & & & & A3 & & & & & \\
\hline
\end{tabular}

Table A2. Pairwise matrices of Expert 2

\begin{tabular}{|c|c|c|c|c|c|c|c|c|c|c|c|c|c|c|c|c|c|c|}
\hline$\overline{\mathrm{C}}$ & $\mathrm{Cl}$ & $\mathrm{C} 2$ & C3 & $\mathrm{C4}$ & & $\mathrm{C1}$ & C11 & $\mathrm{C12}$ & $\mathrm{C} 2$ & C21 & $\mathrm{C} 22$ & & $\mathrm{C3}$ & C31 & C32 & & $\mathrm{C4}$ & C41 C42 \\
\hline$\overline{\mathrm{Cl}}$ & & $1 / \mathrm{Vs}$ & $\mathrm{Wk}$ & $1 / \mathrm{Vs}$ & & C11 & & Es & $\mathrm{C} 21$ & & $1 / \mathrm{Ab}$ & & C31 & & $\mathrm{Ab}$ & & C41 & $\overline{1 / \mathrm{Wk}}$ \\
\hline $\mathrm{C2}$ & & & Vs & Es & & $\mathrm{C12}$ & & & $\mathrm{C} 22$ & & & & $\mathrm{C} 32$ & & & & $\mathrm{C} 42$ & \\
\hline $\mathrm{C} 3$ & & & & $1 / \mathrm{Vs}$ & & & & & & & & & & & & & & \\
\hline \multicolumn{19}{|l|}{$\mathrm{C4}$} \\
\hline$\overline{\mathrm{C11}}$ & A1 & A2 & A3 & & $\mathrm{C12}$ & A1 & A2 & A3 & $\mathrm{C} 21$ & A1 & A2 & A3 & & $\mathrm{C22}$ & A1 & A2 & A3 & \\
\hline$\overline{\mathrm{A1}}$ & & $1 / \mathrm{Es}$ & $\mathrm{Wk}$ & & A1 & & $1 / \mathrm{Es}$ & $1 / \mathrm{Wk}$ & A1 & & $1 / \mathrm{Eq}$ & Es & & A1 & & $\mathrm{Eq}$ & $1 / \mathrm{Wk}$ & \\
\hline$\overline{\mathrm{A} 2}$ & & & Es & & A2 & & & Vs & A2 & & & $\mathrm{Ab}$ & & A2 & & & Es & \\
\hline A3 & & & & & A3 & & & & A3 & & & & & A3 & & & & \\
\hline C31 & A1 & A2 & A3 & & C32 & A1 & A2 & A3 & C41 & A1 & A2 & A3 & & $\mathrm{C} 42$ & A1 & A2 & A3 & \\
\hline$\overline{A 1}$ & & $1 / \mathrm{Vs}$ & $1 / \mathrm{Vs}$ & & A1 & & $1 / \mathrm{Vs}$ & $\mathrm{Wk}$ & A1 & & $1 / \mathrm{Es}$ & $\mathrm{Eq}$ & & A1 & & $1 / \mathrm{Wk}$ & $\mathrm{Eq}$ & \\
\hline$\overline{\mathrm{A} 2}$ & & & $\mathrm{Eq}$ & & A2 & & & Vs & A2 & & & $\mathrm{Wk}$ & & A2 & & & $\mathrm{Eq}$ & \\
\hline A3 & & & & & A3 & & & & A3 & & & & & A3 & & & & \\
\hline
\end{tabular}

Table A3. Pairwise matrices of Expert 3

\begin{tabular}{|c|c|c|c|c|c|c|c|c|c|c|c|c|c|c|c|c|c|c|c|}
\hline $\mathrm{C}$ & C1 & $\mathrm{C} 2$ & $\mathrm{C} 3$ & $\mathrm{C4}$ & & $\mathrm{C} 1$ & C11 & $\mathrm{C} 12$ & $\mathrm{C} 2$ & C21 & $\mathrm{C} 22$ & & $\mathrm{C} 3$ & C31 & $\mathrm{C} 32$ & & $\mathrm{C4}$ & C41 & $\mathrm{C} 42$ \\
\hline $\mathrm{C1}$ & & $1 / \mathrm{Vs}$ & $\mathrm{Wk}$ & $1 / \mathrm{Es}$ & & C11 & & $\mathrm{Ab}$ & $\mathrm{C} 21$ & & $1 / \mathrm{Es}$ & & $\mathrm{C} 31$ & & Vs & & $\mathrm{C41}$ & & $1 / \mathrm{Eq}$ \\
\hline $\mathrm{C} 2$ & & & $\mathrm{Ab}$ & Vs & & $\mathrm{C} 12$ & & & $\mathrm{C} 22$ & & & & $\mathrm{C} 32$ & & & & $\mathrm{C} 42$ & & \\
\hline C3 & & & & $1 /$ Es & & & & & & & & & & & & & & & \\
\hline \multicolumn{20}{|l|}{$\mathrm{C4}$} \\
\hline C11 & A1 & A2 & A3 & & $\mathrm{C12}$ & A1 & A2 & A3 & $\mathrm{C} 21$ & A1 & A2 & A3 & & $\mathrm{C} 22$ & A1 & A2 & A3 & & \\
\hline A1 & & $1 / \mathrm{Vs}$ & $\mathrm{Wk}$ & & A1 & & $1 / \mathrm{Es}$ & $1 / \mathrm{Wk}$ & A1 & & $1 / \mathrm{Eq}$ & Es & & A1 & & $\mathrm{Eq}$ & $1 / \mathrm{Wk}$ & & \\
\hline A2 & & & Es & & A2 & & & Vs & A2 & & & Vs & & A2 & & & Vs & & \\
\hline A3 & & & & & A3 & & & & A3 & & & & & A3 & & & & & \\
\hline C31 & A1 & A2 & A3 & & C32 & A1 & A2 & A3 & C41 & A1 & A2 & A3 & & $\mathrm{C} 42$ & A1 & A2 & A3 & & \\
\hline A1 & & $1 / \mathrm{Vs}$ & $1 / \mathrm{Vs}$ & & A1 & & $1 / \mathrm{Es}$ & $\mathrm{Wk}$ & A1 & & $1 /$ Es & $\mathrm{Eq}$ & & A1 & & $1 / \mathrm{Eq}$ & $\mathrm{Eq}$ & & \\
\hline A2 & & & $\mathrm{Eq}$ & & A2 & & & Vs & A2 & & & $\mathrm{Eq}$ & & A2 & & & Wk & & \\
\hline A3 & & & & & A3 & & & & A3 & & & & & A3 & & & & & \\
\hline
\end{tabular}


Table A4. Linguistic evaluation matrix of Experts

\begin{tabular}{|c|c|c|c|c|c|c|c|c|c|c|c|c|c|c|c|c|}
\hline & \multicolumn{8}{|c|}{ C1 } & \multicolumn{8}{|c|}{$\mathrm{C2}$} \\
\hline & \multicolumn{4}{|c|}{ C11 } & \multicolumn{4}{|c|}{$\mathrm{C12}$} & \multicolumn{4}{|c|}{ C21 } & \multicolumn{4}{|c|}{$\mathrm{C22}$} \\
\hline & E1 & E2 & E3 & $\mathrm{C}^{*}$ & E1 & E2 & E3 & $\mathrm{C}$ & E1 & E2 & E3 & $\mathrm{C}$ & E1 & E2 & E3 & $\mathrm{C}$ \\
\hline A1 & $\mathrm{VH}$ & $\mathrm{H}$ & $\mathrm{M}$ & $\mathrm{H}$ & VH & $\mathrm{M}$ & $\mathrm{M}$ & $M$ & M & $\mathrm{H}$ & $\mathrm{H}$ & $\mathrm{H}$ & $\mathrm{H}$ & $\mathrm{M}$ & $\mathrm{M}$ & M \\
\hline A2 & $\mathrm{M}$ & $\mathrm{VH}$ & $\mathrm{H}$ & $\mathrm{H}$ & $\mathrm{L}$ & $\mathrm{VH}$ & $\mathrm{H}$ & $\mathrm{H}$ & $\mathrm{H}$ & $\mathrm{VH}$ & $\mathrm{VH}$ & $\mathrm{VH}$ & $\mathrm{M}$ & $\mathrm{H}$ & $\mathrm{H}$ & $\mathrm{H}$ \\
\hline \multirow[t]{4}{*}{ A3 } & $\mathrm{H}$ & M & $\mathrm{M}$ & M & M & $\mathrm{H}$ & VH & $\mathrm{H}$ & M & $\mathrm{L}$ & M & M & $\mathrm{H}$ & M & M & M \\
\hline & \multicolumn{8}{|c|}{ C3 } & \multicolumn{8}{|c|}{ C4 } \\
\hline & \multicolumn{4}{|c|}{ C31 } & \multicolumn{4}{|c|}{ C32 } & \multicolumn{4}{|c|}{ C41 } & \multicolumn{4}{|c|}{$\mathrm{C42}$} \\
\hline & E1 & E2 & E3 & $\mathrm{C}$ & E1 & E2 & E3 & $\mathrm{C}$ & E1 & E2 & E3 & $\mathrm{C}$ & E1 & E2 & E3 & $\mathrm{C}$ \\
\hline A1 & $\mathrm{VH}$ & $\mathrm{M}$ & $\mathrm{M}$ & $\mathrm{M}$ & $\mathrm{H}$ & $\mathrm{H}$ & $\mathrm{H}$ & $\mathrm{H}$ & $\mathrm{VH}$ & $\mathrm{M}$ & $\mathrm{L}$ & $\mathrm{M}$ & $\mathrm{H}$ & $\mathrm{M}$ & $\mathrm{M}$ & $\mathrm{M}$ \\
\hline A2 & $\mathrm{VH}$ & $\mathrm{H}$ & $\mathrm{H}$ & $\mathrm{H}$ & $\mathrm{L}$ & $\mathrm{VH}$ & $\mathrm{VH}$ & $\mathrm{VH}$ & M & VH & $\mathrm{M}$ & $\mathrm{H}$ & $\mathrm{M}$ & $\mathrm{H}$ & $\mathrm{H}$ & $\mathrm{H}$ \\
\hline A3 & $\mathrm{M}$ & $\mathrm{H}$ & $\mathrm{M}$ & $\mathrm{M}$ & $M$ & $\mathrm{M}$ & $\mathrm{M}$ & $\mathrm{M}$ & $\mathrm{VH}$ & $\mathrm{M}$ & $\mathrm{L}$ & M & $\mathrm{M}$ & $\mathrm{H}$ & $\mathrm{M}$ & $\mathrm{M}$ \\
\hline
\end{tabular}

* “C" represents the consensus matrix

Cengiz KAHRAMAN. A full time Professor at Istanbul Technical University, Industrial Engineering Department. He is presently the head of Industrial Engineering Department. He published more than 150 international journal papers, more than 150 international conference papers and edited 5 Springer books. He also guest-edited many special issues of international journals. His research areas include multiple criteria decision making, fuzzy sets, quality control, engineering economics, and statistical decision making.

Asli SUDER. An Associate Professor of Management and Organization at Istanbul Technical University, Faculty of Management and Department of Management Engineering, in Turkey. She graduated from Bosporus University Department of Management in 1976. She continued her education and also earned a Bachelor's Degree in Economics and Administrative Sciences from Marmara University, in 1981, a Master's Degree in International Management from Istanbul University, in 1982, and finally a Philosophy Degree in International Management in 1987 from Social Sciences Institute of Istanbul University. She begun to work as a Research Assistant in Istanbul Technical University in 1982 and she became an Assistant Professor in 1991 and Associate Professor in 2007 at the same university. Since 1982 she has been a faculty member, and teaching in Management and Organization, Organizational Theory, Organizational Behavior, Human Resource Management at the undergraduate level and Management and Organization, Organizational Behavior, and Strategic Human Resource Management at the graduate level. She is the author of numerous scientific publications. She has published extensively in the fields of management and organization, human resource management, project management, healthcare management, social responsibility and ethics, logistics and green management, crisis and risk management, decision making.

Selcuk CEBI. An Associate Professor at the Department of Industrial Engineering at Karadeniz Technical University. He received his $\mathrm{PhD}$ from Istanbul Technical University in 2010. He has published over 60 research articles in various journals, conferences, and books. His journal publications include Expert Systems with Applications, Information Sciences, Knowledge-based Systems, Decision Support Systems, Energy, Accident Analysis \& Prevention, Electronic Commerce Research and Applications, International Journal of Computational Intelligence Systems, Journal of Multiple-Valued Logic and Soft Computing. His current research interests are decision support systems, multiple criteria decision making, human-computer interactions, and interface design. 